\title{
Patterns of growth among children who later develop type 2 diabetes or its risk factors
}

\author{
J. G. Eriksson • C. Osmond • E. Kajantie • T. J. Forsén • \\ D. J. P. Barker
}

Received: 23 May 2006 / Accepted: 25 August 2006 / Published online: 3 October 2006

(C) Springer-Verlag 2006

\begin{abstract}
Aims/hypothesis We studied fetal and childhood growth patterns that are associated with IGT and type 2 diabetes in adult life.

Methods We examined clinically 2,003 subjects born in Helsinki between 1934 and 1944. They had on average 11 measurements of height and weight between birth and 2 years of age, and seven measurements between 2 and 11 years of age. Glucose tolerance in adult life was assessed by a 75 -g oral glucose tolerance test.

Results We identified 311 subjects with type 2 diabetes and 496 with IGT. Both IGT and type 2 diabetes were associated with low birthweight $(p<0.0001$ adjusting for current BMI). The risk of these conditions was increased by low weight gain between birth and 2 years. A 1 SD increase in weight at 2 years was associated with an odds ratio for either type 2 diabetes or IGT of 0.76 (95\% CI $0.69-0.84)$. This effect was greatest in people who had low birthweight.
\end{abstract}

J. G. Eriksson • E. Kajantie • T. J. Forsén

National Public Health Institute,

Helsinki, Finland

J. G. Eriksson $(\bowtie)$

Department of Public Health, University of Helsinki, 00014 Helsinki, Finland

e-mail: Johan.Eriksson@helsinki.fi

C. Osmond

MRC Epidemiology Resource Centre,

University of Southampton, Southampton General Hospital,

Southampton, UK

D. J. P. Barker

DOHaD Division, University of Southampton,

Southampton General Hospital,

Southampton, UK
Low growth in the first 6 months after birth was a critical period for the development of insulin resistance in later life; other critical periods were associated with slow fetal growth and rapid increase in BMI between age 2 and 11 years.

Conclusions/interpretation Low weight gain during infancy increases the risk of IGT and type 2 diabetes. The effect is greater in people who had low birthweight. The first 6 months after birth may be the most critical period for growth, in relation to development of glucose intolerance.

Keywords Childhood growth $\cdot$ Fetal growth $\cdot$ IGT .

Type 2 diabetes

$\begin{array}{ll}\text { Abbreviations } \\ \text { HOMA-IR } & \begin{array}{l}\text { homeostasis model assessment of insulin } \\ \text { resistance } \\ \text { odds ratio }\end{array}\end{array}$

\section{Introduction}

We have previously examined the fetal, infant and childhood growth of people who developed CHD in a cohort of 8,760 subjects born in Helsinki, Finland [1]. Children who later developed CHD were small at birth and thin at about 2 years of age. Between 2 and 11 years old they put on weight more rapidly than the other children. Low birthweight, thinness at 2 years and rapid gain in BMI thereafter each contributed to the risk of CHD.

We have now explored the associations between early growth patterns and glucose metabolism in adulthood, addressing also the question of whether there are critical ages between birth and 2 years at which slow growth affects glucose and insulin metabolism in adult life. 


\section{Subjects and methods}

Subjects and study design

The original birth cohort consisted of 8,760 people who were born as singletons at Helsinki University Central Hospital between 1934 and 1944, and who attended child welfare clinics and were resident in Finland in 1971. The majority (77\%) went to school in the city. Their birth records include information on birthweight and length at birth. The child welfare clinic and school health care records include information on growth between birth and 11 years of age. On average each person had 11 measurements of height and weight between birth and 2 years of age, and seven measurements between 2 and 11 years. Details of the birth, child welfare clinic and school health care records have been described previously $[2,3]$.

From the original study cohort 2,003 men and women were randomly selected to attend a clinical examination, which included a standard 75-g OGTT. Plasma glucose and insulin concentrations were measured at baseline and $120 \mathrm{~min}$.

Height was measured to the nearest $0.1 \mathrm{~cm}$ and weight was measured to the nearest $0.1 \mathrm{~kg}$. Plasma glucose was measured by a hexokinase method [4]. Plasma insulin concentrations were determined by a twosite immunometric assay [5]. Homeostasis model assessment of insulin resistance (HOMA- IR $)$ is the product of fasting glucose and insulin concentrations divided by 22.5 , and was used as a measure of insulin resistance [6].

The diagnosis of diabetes was based upon an OGTT and the WHO 1999 criteria for glucose intolerance [7].

The study was approved by the local Ethical Committee and informed written consent was obtained from the participants.

\section{Statistical methods}

Data were analysed by tabulation of means and multiple linear and logistic regression. We use the residuals from regression analysis to measure to what degree size at a later age differed from the prediction using earlier size, and we refer to these residuals as measures of 'conditional growth'. By this construction, conditional growth is uncorrelated with the earlier size measurements. Levels of significance refer to analyses of continuous variables. Plasma glucose and insulin concentrations and HOMA-IR index had skewed distributions and were log-transformed for analysis.

\section{Results}

IGT and type 2 diabetes

In total 2003 persons (1,075 women and 928 men) participated in the study. Of these, 496 subjects were diagnosed as having IGT and 311 as having type 2 diabetes.

\section{Size at birth}

Table 1 shows that across the range of birthweights there was a fall in fasting insulin and 2-h glucose and insulin concentrations. HOMA-IR values also fell as did the odds ratios (ORs) for IGT and type 2 diabetes. A 1-kg increase in birthweight was associated with an OR for either IGT or type 2 diabetes of 0.64 (95\% CI $0.53-0.78)$. ORs for either IGT or type 2 diabetes also fell with increasing birth length $(p=0.0005)$, ponderal index at birth $(p=0.02)$ and BMI at birth $(p=0.0003)$. The ORs were unrelated to gestational age. The relationship between birthweight and fasting insulin levels and HOMA were statistically significant only after adjustment for current BMI.

Growth from birth to 2 years

Table 2 shows that low weight at 2 years of age was a strong predictor of several markers of glucose and insulin metabolism. A 1 SD increase in weight at 2 years was associated with an OR for either IGT or type 2 diabetes of 0.76 (95\% CI 0.69-0.84) after adjusting for current body size. The corresponding ORs for length and BMI at 2 years were 0.83 (95\% CI $0.76-0.92)$ and 0.82 (95\% CI 0.74 $0.90)$, respectively. Short length at 2 years was associated with all 2-h measurements and with ORs $(p<0.01$ after adjustment for age, sex and current BMI). In contrast BMI at 2 years was associated with both the fasting and 2-h measurements and ORs $(p<0.005$ after adjustment for age, sex and current BMI) but not with the fasting measurements $(p>0.3)$. The findings were similar among men and women, although they were in general stronger among women.

Low weight at 2 years had a stronger impact on the risk of IGT and type 2 diabetes among people who had low birthweight ( $p$ for interaction $=0.04$ and 0.03 for diabetes alone). The highest ORs, i.e. 2.6 (95\% CI $1.8-3.7)$, were among people whose birthweights were below $3,000 \mathrm{~g}$ and whose weights at 2 years were below $11.5 \mathrm{~kg}$. There was a similar interaction between birthweight and short length at 2 years ( $p$ for interaction $=0.05$; adjusted $p=0.04$ ). No statistically significant interactions were observed between the effects of birthweight and either weight or length at 2 years on plasma glucose or insulin concentrations ( $p$ for interaction $>0.17$ ). 
Table 1 Fasting and 2-h plasma glucose and insulin concentrations, HOMA-IR and ORs for IGT and type 2 diabetes according to birthweight

\begin{tabular}{|c|c|c|c|c|c|c|c|}
\hline \multicolumn{3}{|l|}{ Fasting } & \multicolumn{2}{|l|}{$2-\mathrm{h}$} & \multicolumn{3}{|c|}{ Odds ratios } \\
\hline $\begin{array}{l}\text { Glucose } \\
(\mathrm{mmol} / \mathrm{l})^{*}\end{array}$ & $\begin{array}{l}\text { Insulin } \\
(\mu \mathrm{U} / \mathrm{ml})^{*}\end{array}$ & HOMA* & $\begin{array}{l}\text { Glucose } \\
(\mathrm{mmol} / \mathrm{l})^{*}\end{array}$ & $\begin{array}{l}\text { Insulin } \\
(\mu \mathrm{U} / \mathrm{ml})^{*}\end{array}$ & IGT & $\mathrm{T} 2 \mathrm{DM}$ & $\begin{array}{l}\text { IGT and } \\
\text { T2DM }\end{array}$ \\
\hline
\end{tabular}

\begin{tabular}{|c|c|c|c|c|c|c|c|c|}
\hline \multicolumn{9}{|l|}{ Birthweight $(\mathrm{kg})(n)$} \\
\hline$-2.5(72)$ & 5.6 & 8.4 & 2.1 & 7.1 & 59 & 2.75 & 1.70 & 2.47 \\
\hline$-3.0(324)$ & 5.6 & 9.4 & 2.3 & 7.3 & 66 & 1.65 & 2.36 & 1.86 \\
\hline$-3.5(792)$ & 5.6 & 8.3 & 2.1 & 7.1 & 61 & 1.55 & 1.63 & 1.56 \\
\hline$-4.0(613)$ & 5.6 & 8.1 & 2.0 & 6.9 & 55 & 1.19 & 1.21 & 1.18 \\
\hline$>4.0(202)$ & 5.5 & 8.1 & 2.0 & 6.7 & 52 & 1.0 & 1.0 & 1.0 \\
\hline$p$ values for trend $* *$ & 0.8 & 0.6 & 0.66 & 0.08 & 0.009 & 0.002 & 0.05 & 0.001 \\
\hline Change/OR associated with & $-0.1 \%$ & $-1.8 \%$ & $-1.6 \%$ & $-2.6 \%$ & $-9.1 \%$ & 0.71 & 0.77 & 0.73 \\
\hline $1 \mathrm{~kg}$ increase in birthweight** & $\begin{array}{l}(-1.1 \text { to } \\
1.4)\end{array}$ & $\begin{array}{l}(-7.4 \text { to } \\
4.2)\end{array}$ & $\begin{array}{l}(-7.8 \text { to } \\
4.9)\end{array}$ & $\begin{array}{l}(-5.5 \text { to } \\
0.3)\end{array}$ & $\begin{array}{l}(-15.4 \text { to } \\
-2.4)\end{array}$ & $\begin{array}{l}(0.57 \text { to } \\
0.88)\end{array}$ & $\begin{array}{l}(0.59 \text { to } \\
1.00)\end{array}$ & $\begin{array}{l}(0.60 \text { to } \\
0.88)\end{array}$ \\
\hline$p$ values for trend $* * *$ & 0.3 & 0.002 & 0.002 & 0.004 & $<0.0001$ & 0.0004 & 0.0005 & $<0.0001$ \\
\hline $\begin{array}{l}\text { Change/OR associated with } \\
1 \mathrm{~kg} \text { increase in } \\
\text { birthweight*** }\end{array}$ & $\begin{array}{l}-0.6 \% \\
(-1.8 \text { to } \\
0.6)\end{array}$ & $\begin{array}{l}-7.7 \% \\
(-12.3 \text { to } \\
-2.8)\end{array}$ & $\begin{array}{l}-8.2 \% \\
(-13.1 \text { to } \\
-3.0)\end{array}$ & $\begin{array}{l}-4.2 \% \\
(-6.9 \text { to } \\
-1.3)\end{array}$ & $\begin{array}{l}-13.8 \% \\
(-19.4 \text { to } \\
-7.8)\end{array}$ & $\begin{array}{l}0.66 \\
(0.53 \text { to } \\
0.83)\end{array}$ & $\begin{array}{l}0.61 \\
(0.61 \text { to } \\
0.81)\end{array}$ & $\begin{array}{l}0.64 \\
(0.53 \text { to } \\
0.78)\end{array}$ \\
\hline
\end{tabular}

* Geometric means

**Values are adjusted for age and sex

$* * *$ Values are adjusted for age, sex and current BMI

$H O M A_{-I R}$, homeostasis model assessment of insulin resistance; $O R$, odds ratio; T2DM, type 2 diabetes mellitus

We examined the effects of weight gain during three periods of infancy, birth to 6 months, 6 months to 1 year and 1 to 2 years. In these analyses the effect of weight at each age takes the preceding weights into account using linear regression so that the residuals are analysed. Low weight gain in the first 6 months after birth was related to high values for all measurements and ORs examined (Table 3). The effects of low weight gain in the next 6month period were weaker in relation to glucose and insulin concentrations, but low weight gain still predicted IGT and type 2 diabetes. Weight gain between 1 and 2 years was the weakest predictor.

Table 2 Fasting and 2-h plasma glucose and insulin concentrations, HOMA-IR and ORs for IGT and type 2 diabetes, according to weight at 2 years old

\begin{tabular}{|c|c|c|c|c|c|c|c|}
\hline \multicolumn{3}{|l|}{ Fasting } & \multicolumn{2}{|l|}{$2-h$} & \multicolumn{3}{|l|}{ Odds ratios } \\
\hline $\begin{array}{l}\text { Glucose } \\
(\mathrm{mmol} / \mathrm{l})^{*}\end{array}$ & $\begin{array}{l}\text { Insulin } \\
\left(\mu \mathrm{U} / \mathrm{m} l^{*}\right)\end{array}$ & HOMA* & $\begin{array}{l}\text { Glucose } \\
(\mathrm{mmol} / \mathrm{l})^{*}\end{array}$ & $\begin{array}{l}\text { Insulin } \\
(\mu \mathrm{U} / \mathrm{ml})^{*}\end{array}$ & IGT & $\mathrm{T} 2 \mathrm{DM}$ & $\begin{array}{l}\text { IGT and } \\
\text { T2DM }\end{array}$ \\
\hline 5.7 & 9.3 & 2.3 & 7.5 & 67 & 1.77 & 2.95 & 2.22 \\
\hline 5.6 & 8.7 & 2.2 & 7.2 & 64 & 1.42 & 1.88 & 1.61 \\
\hline 5.5 & 8.1 & 2.0 & 7.1 & 58 & 1.70 & 1.21 & 1.57 \\
\hline 5.6 & 8.0 & 2.0 & 6.9 & 56 & 1.14 & 1.71 & 1.35 \\
\hline 5.5 & 7.8 & 1.9 & 6.7 & 50 & 1.00 & 1.00 & 1.00 \\
\hline 0.1 & 0.03 & 0.02 & $<0.0001$ & $<0.0001$ & 0.006 & $<0.0001$ & $<0.0001$ \\
\hline $\begin{array}{l}-0.5 \% \\
(-1.1 \text { to } \\
0.0)\end{array}$ & $\begin{array}{l}-3.3 \% \\
(-6.2 \text { to } \\
-0.4)\end{array}$ & $\begin{array}{l}-3.8 \% \\
(-6.8 \text { to } \\
-0.6)\end{array}$ & $\begin{array}{l}-3.5 \% \\
(-4.9 \text { to } \\
-2.0)\end{array}$ & $\begin{array}{l}-7.6 \% \\
(-10.9 \text { to } \\
-4.2)\end{array}$ & $\begin{array}{l}0.85(0.76 \\
\text { to } 0.96)\end{array}$ & $\begin{array}{c}0.75(0.65 \\
\text { to } 0.85)\end{array}$ & $\begin{array}{l}0.81 \\
(0.74 \text { to } \\
0.89)\end{array}$ \\
\hline 0.006 & $<0.0001$ & $<0.0001$ & $<0.0001$ & $<0.0001$ & 0.0006 & $<0.0001$ & $<0.0001$ \\
\hline $\begin{array}{l}-0.8 \% \\
(-1.4 \text { to } \\
-0.2)\end{array}$ & $\begin{array}{l}-6.2 \% \\
(-8.6 \text { to } \\
-4.7)\end{array}$ & $\begin{array}{l}-7.0 \% \\
(-9.5 \text { to } \\
-4.4)\end{array}$ & $\begin{array}{l}-4.3 \% \\
(-5.6 \text { to } \\
-2.9)\end{array}$ & $\begin{array}{l}-10.0 \% \\
(-13.0 \text { to } \\
-7.0)\end{array}$ & $\begin{array}{c}0.83(0.73 \\
\text { to } 0.92)\end{array}$ & $\begin{array}{c}0.69(0.60 \\
\text { to } 0.80)\end{array}$ & $\begin{array}{l}0.76 \\
(0.69 \text { to } \\
0.84)\end{array}$ \\
\hline
\end{tabular}

*Geometric means

$* *$ Values are adjusted for age and sex

$* * *$ Values are adjusted for age, sex and current BMI

$H O M A_{I R}$, homeostasis model assessment of insulin resistance; $O R$, odds ratio; T2DM, type 2 diabetes mellitus 
Table 3 Fasting and 2-h plasma glucose and insulin concentrations, HOMA- ${ }_{\text {IR }}$ and ORs for IGT and type 2 diabetes, according to weight change between birth and 6 months

\begin{tabular}{llllllll}
$\begin{array}{l}\text { Glucose } \\
(\mathrm{mmol} / \mathrm{l})^{*}\end{array}$ & $\begin{array}{l}\text { Insulin } \\
(\mu \mathrm{U} / \mathrm{ml})^{*}\end{array}$ & HOMA $^{*}$ & $\begin{array}{l}\text { Glucose } \\
(\mathrm{mmol} / \mathrm{l}) *\end{array}$ & $\begin{array}{l}\text { Insulin } \\
(\mu \mathrm{U} / \mathrm{ml})^{*}\end{array}$ & IGT & T2DM & $\begin{array}{l}\text { IGT and } \\
\text { T2DM }\end{array}$ \\
\hline
\end{tabular}

Weight at 6 months adjusted for birthweight $(n)$

1 lowest (400)

$2(401)$

3 (401)

4 (401)

5 highest (400)

$p$ values for trend $* *$

Change/OR associated with $1 \mathrm{SD}$

increase $(95 \% \mathrm{CI}) * *$

$p$ values for trend $* * *$

Change/OR associated with $1 \mathrm{SD}$

increase $(95 \% \mathrm{CI}) * * *$

5.6

5.6

5.6

5.6

5.5

0.08

$-0.5 \%$

$(-1.1$ to

$0.1)$

0.03

$-0.6 \%$

$(-1.2$ to

$-0.1)$

8.8
8.7
8.4
8.2
7.8
0.005
$-3.9 \%$
$(-6.6$ to
$-1.2)$
$<0.0001$
$-4.9 \%$
$(-7.2$ to
$-2.6)$

8.8

8.4

\section{2}

2.2

2.1

2.0

1.9

0.004

$-4.4 \%$

(-7.3 to

$-1.5)$

$<0.0001$

$-5.5 \%$

(-7.9 to

$-3.0)$

$(\mathrm{mmol} / \mathrm{l})^{*}$

$(\mu \mathrm{U} / \mathrm{ml})^{*}$

T2DM

*Geometric means

**Values are adjusted for age and sex

***Values are adjusted for age, sex and current BMI

The cut-off points for body weight at 6 months conditional on birthweight among men are: drop by $0.85 \mathrm{~kg}$, drop by $0.22 \mathrm{~kg}$, rise by $0.24 \mathrm{~kg}$ and rise by $0.81 \mathrm{~kg}$, The corresponding cut-off points among women are: drop by $0.82 \mathrm{~kg}$, drop by $0.28 \mathrm{~kg}$, rise by $0.26 \mathrm{~kg}$ and rise by $0.83 \mathrm{~kg}$. $H O M A-_{I R}$, homeostasis model assessment of insulin resistance; $O R$, odds ratio; T2DM, type 2 diabetes mellitus

We examined the separate effect of linear growth and soft tissue growth as indicated by BMI. In the first 6 months after birth, later IGT and type 2 diabetes were predicted by low gain in BMI (adjusted for sex, current age and BMI). A $1 \mathrm{SD}$ of BMI gain was associated with an OR of $0.87(95 \%$ CI $0.80-0.96$ ), whereas from 6 to 12 months IGT and type 2 diabetes were predicted by low gain in either height (OR 0.89 ; $95 \%$ CI $0.81-0.98$ ) or BMI (OR 0.90; $95 \%$ CI $0.82-$ $0.99)$.
Growth from 2 to 11 years

Between the ages of 2 and 11 years a rapid increase in BMI predicted raised values for insulin but not for glucose measurements. In Table 4 the values are not adjusted for current BMI. Such adjustment abolishes the effect of rapid increase in BMI, which was correlated with current BMI $(r=0.17 ; p<0.0001)$. The OR for IGT and type 2 diabetes was $1.13(95 \%$ CI $1.11-1.16)$ per $1 \mathrm{~kg} / \mathrm{m}^{2}$ increase in adult BMI $(p<0.0001)$. A 1 SD increase in BMI between 2 and

Table 4 Fasting and 2-h plasma glucose and insulin concentrations, HOMA-IR and ORs for IGT and type 2 diabetes, according to change in $Z$ score for BMI between 2 and 11 years of age

\begin{tabular}{|c|c|c|c|c|c|c|c|c|}
\hline & \multicolumn{3}{|l|}{ Fasting } & \multicolumn{2}{|l|}{$2-\mathrm{h}$} & \multicolumn{3}{|c|}{ Odds ratios } \\
\hline & $\begin{array}{l}\text { Glucose } \\
(\mathrm{mmol} / \mathrm{l})^{*}\end{array}$ & $\begin{array}{l}\text { Insulin } \\
(\mu \mathrm{U} / \mathrm{ml})^{*}\end{array}$ & HOMA* & $\begin{array}{l}\text { Glucose } \\
(\mathrm{mmol} / 1)^{*}\end{array}$ & $\begin{array}{l}\text { Insulin } \\
(\mu \mathrm{U} / \mathrm{ml})^{*}\end{array}$ & IGT & $\mathrm{T} 2 \mathrm{DM}$ & $\begin{array}{l}\text { IGT and } \\
\text { T2DM }\end{array}$ \\
\hline \multicolumn{9}{|l|}{ Changes $(n)$} \\
\hline Fall $>1(314)$ & 5.6 & 7.9 & 2.0 & 7.0 & 57 & 1.00 & 1.00 & 1.00 \\
\hline Fall 0.25 to $1(469)$ & 5.5 & 8.2 & 2.0 & 6.9 & 56 & 1.17 & 0.66 & 0.97 \\
\hline Fall 0.25 to increase 0.25 (385) & 5.6 & 8.4 & 2.1 & 7.1 & 61 & 1.34 & 1.32 & 1.34 \\
\hline Increase 0.25 to 1 (429) & 5.6 & 8.3 & 2.1 & 7.1 & 58 & 1.14 & 1.16 & 1.16 \\
\hline Increase $>1(320)$ & 5.6 & 9.2 & 2.3 & 7.2 & 63 & 1.28 & 1.37 & 1.35 \\
\hline$p$ value & 0.5 & 0.0004 & 0.0007 & 0.1 & 0.04 & 0.2 & 0.004 & 0.01 \\
\hline Change/OR associated with 1 & $0.2 \%$ & $5.2 \%$ & $5.4 \%$ & $1.1 \%$ & $3.7 \%$ & 1.06 & 1.20 & 1.12 \\
\hline SD increase $(95 \% \mathrm{CI})$ & $(-0.4$ to & (2.3 to & (2.3 to & $(-0.3$ to & (0.3 to & (0.96 to & (1.06 to & (1.03 to \\
\hline & $0.8)$ & $8.2)$ & $8.6)$ & 2.6) & $7.3)$ & $1.18)$ & $1.35)$ & $1.22)$ \\
\hline
\end{tabular}

*Geometric means

$H O M A-_{I R}$, homeostasis model assessment of insulin resistance; $O R$, odds ratio; T2DM, type 2 diabetes mellitus 
11 years was associated with an OR of 1.12 for IGT and type 2 diabetes (95\% CI 1.03-1.22). An increase in height between 2 and 11 years was also associated with IGT and type 2 diabetes in adult life (OR 1.18 [95\% CI 1.05-1.32; $p=0.005])$.

\section{Discussion}

We have examined the associations between fetal, infant and childhood growth and the development of IGT or type 2 diabetes in adult life. Both of these conditions were associated with low birthweight, as has been shown before [8-14]. They were also associated with low weight gain between birth and 2 years of age; this had a greater effect among people who had low birthweight. Between 2 and 11 years an increase in $Z$ scores for BMI further increased the risk of these conditions, as we have previously shown [14].

Our cohort was restricted to people who were born in Helsinki and who had attended child welfare clinics. While the people in our study may therefore be unrepresentative of all people living in Helsinki at that time, at birth their social class distribution, as indicated by their father's occupation, was similar to that of the city as a whole. For this clinical examination we selected at random 2,003 people from the total birth cohort of 8,760 individuals. Their body size at birth and growth during childhood were similar to that of the whole cohort.

We found that the risk of IGT or type 2 diabetes was increased by low gain in weight and BMI, or slow linear growth between birth and 2 years of age. This is consistent with the association between low weight at 1 year and later type 2 diabetes among men in Hertfordshire, UK [8]. A study of people born in Delhi showed that thinness at about 2 years of age followed by rapid increase in BMI was associated with increased risk of IGT and type 2 diabetes in a group of men and women about 30 years of age [13]. In our study, low weight and height at 2 years of age had a more marked effect on the risk of IGT and type 2 diabetes among people of lower birthweight. This interaction has not been described before.

We found no evidence to support the hypothesis that promotion of early growth by high nutrient intakes in the first few months after birth adversely affect later glucose and insulin metabolism [15]. We examined weight gain at different ages between birth and 2 years and found that slow weight gain in the first 6 months after birth caused the largest increase in fasting and 2-h concentrations of glucose and insulin. Slow growth throughout the first year after birth predicted both IGT and type 2 diabetes.

Our observations on the links between low birthweight and later development of IGT and type 2 diabetes are consistent with the hypothesis that low birthweight is associated with insulin resistance. Reduced muscle mass and muscle insensitivity to insulin have been proposed as mechanisms for this association [16-19]. Much of muscle development is complete before birth [20]. We suggest that failure of early postnatal growth aggravates insulin resistance, as skeletal muscle continues to develop for some months after birth. We found that after 6 months low weight gain had small effects on later insulin resistance. However, low weight gain between 6 months and 1 year did increase the risk of later type 2 diabetes. We speculate that this may be due to impaired development of the endocrine pancreas since the phase of remodelling of the islets continues from late gestation onwards until adolescence [21, 22].

We found that while slow linear growth up to the age of 2 years was associated with raised 2-h glucose and insulin concentrations, slow soft tissue growth leading to a low BMI at 2 years of age was associated with both elevated fasting and 2-h glucose and with elevated insulin values. Fasting glucose concentrations are related to hepatic glucose production. A possible implication of our findings is that slow linear growth in infancy is associated with persisting metabolic defects in muscle, whereas slow soft tissue growth affects both muscle and liver. We found that the effects of slow linear growth between birth and 2 years were greater in people who had low birthweight. There was no similar interaction between the effects of birthweight and low increase in BMI. The effects of slow linear growth on muscle bulk and metabolism may aggravate those already established through slow growth in utero. Increase in BMI between 2 and 11 years may increase the risk of IGT and type 2 diabetes by increasing fat mass rather than muscle mass, leading to a body composition that predisposes to type 2 diabetes and other manifestations of insulin resistance.

However, adjustment for adult degree of obesity abolished these correlations between increases in childhood BMI between 2 and 11 years and later glucose intolerance. This could be due to the close association between childhood and adult BMI [23]. In other words gaining more weight in childhood gives you a higher BMI in adult life- a well-known risk for type 2 diabetes.

Type 1 and type 2 diabetes share several metabolic characteristics. However, the early life risk factors predisposing to the diseases differ. Children with a high birthweight have an increased risk of type 1 diabetes, while those with a low birthweight have a lower risk of that disease $[24,25]$. According to the original fetal origins hypothesis, a small body size at birth is linked to an increased risk of type 2 diabetes, primarily mediated through peripheral insulin resistance. The underlying causes for the early life differences between type 1 and type 2 diabetes are not known, but it has been speculated that the 
larger fetus could develop a beta cell phenotype that is more liable to necrosis and apoptosis, thereby predisposing to type 1 diabetes [25].

The differences in growth patterns between offspring who develop type 1 and 2 diabetes are not restricted to fetal life. Increases in height and weight during infancy predispose to type 1 diabetes, while a small body size during this time period is linked to type 2 diabetes. Despite differences in growth patterns, these findings support the early-origins-of-adult-diseases hypothesis on the development of type 1 and type 2 diabetes. In connection, moreover, with the primary prevention of type 1 and type 2 diabetes, it is important to stress the role of prevention strategies aimed at optimal growth and nutrition of pregnant women and young children.

In conclusion we have found that low rates of linear growth or soft tissue growth during infancy increase the risk of type 2 diabetes. The effect is greater in people who had low birthweight. The first 6 months after birth may be the most critical period for infant growth in relation to development of IGT and type 2 diabetes.

Acknowledgement This study was supported by the British Heart Foundation, the Academy of Finland, The Päivikki and Sakari Sohlberg Foundation, The Finnish Diabetes Research Foundation, The Finnish Foundation for Cardiovascular Research, the Foundation for Paediatric Research, The Finnish Medical Society Duodecim, the Yrjö Jahnsson Foundation, The Signe and Ane Gyllenberg Foundation and the Medical Society of Finland (Finska Läkaresällskapet).

\section{References}

1. Barker DJ, Osmond C, Forsen TJ, Kajantie E, Eriksson JG (2005) Trajectories of growth among children who have coronary events as adults. N Engl J Med 27:1802-1809

2. Eriksson JG, Forsen T, Tuomilehto J, Osmond C, Barker DJP (2001) Early growth and coronary heart disease in later life: longitudinal study. Br Med J 322:949-953

3. Forsen T, Osmond C, Eriksson JG, Barker DJP (2004) Growth of girls who later develop coronary heart disease. Heart 90:20-24

4. Kunst A, Draeger B, Ziegenhorn J (1983) UV-methods with hexokinase and glucose-6-phosphate dehydrogenase. In: Bergmeyer HU (ed) Methods of enzymatic analysis. Verlag Chemie, Weinheim, pp $163-172$

5. Sobey WJ, Beer SF, Carrington CA et al (1989) Sensitive and specific two-site immunoradiometric assays for human insulin, proinsulin, 65-66 split and 32-33 split proinsulins. Biochem J 260:535-541

6. Matthews DR, Hosker JP, Rudenski AS, Naylor BA, Treacher DF, Turner RC (1985) Homeostasis model assessment: insulin resistance and beta-cell function from fasting plasma glucose and insulin concentrations in man. Diabetologia 28:412-419
7. World Health Organization (1999) Definition, diagnosis, and classification of diabetes mellitus and its complications: Report of a WHO Consultation. Part 1: Diagnosis and classification of diabetes mellitus. WHO, Geneva

8. Hales CN, Barker DJ, Clark PM et al (1991) Fetal and infant growth and impaired glucose tolerance at age $64 . \mathrm{Br}$ Med $\mathrm{J}$ 303:1019-1022

9. Lithell HO, McKeigue PM, Berglund L, Mohsen R, Lithell UB, Leon DA (1996) Relation of size at birth to non-insulin dependent diabetes and insulin concentrations in men aged 50-60 years. Br Med J 312:406-410

10. Phillips DIW (1996) Insulin resistance as a programmed response to fetal undernutrition. Diabetologia 39:1119-1122

11. Forsen T, Eriksson J, Tuomilehto J, Reunanen A, Osmond C, Barker D (2000) The fetal and childhood growth of persons who develop type 2 diabetes. Ann Intern Med 133:176-182

12. Harding JE (2001) The nutritional basis of the fetal origins of adult disease. Int $\mathrm{J}$ Epidemiol 30:15-23

13. Bhargava SK, Sachdev HS, Fall CH et al (2004) Relation of serial changes in childhood body mass index to impaired glucose tolerance in young adulthood. N Engl J Med 350:865-875

14. Eriksson JG, Forsen TJ, Osmond C, Barker DJ (2003) Pathways of infant and childhood growth that lead to type 2 diabetes. Diabetes Care 26:3006-3010

15. Singhal A, Fewtrell M, Cole TJ, Lucas A (2003) Low nutrient intake and early growth for later insulin resistance in adolescents born preterm. Lancet 361:1089-1097

16. Kahn HS, Narayan KM, Williamson DF, Valdez R (2000) Relation of birth weight to lean and fat thigh tissue in young men. Int J Obes Relat Metab Disord 24:667-672

17. Eriksson J, Forsen T, Tuomilehto J, Osmond C, Barker D (2002) Size at birth, fat-free mass and resting metabolic rate in adult life. Horm Metab Res 34:72-76

18. Kensara OA, Wootton SA, Phillips DI, Patel M, Jackson AA, Elia M (2005) Fetal programming of body composition: relation between birth weight and body composition measured with dualenergy X-ray absorptiometry and anthropometric methods in older Englishmen. Am J Clin Nutr 82:980-987

19. Sachdev HS, Fall CH, Osmond C et al (2005) Anthropometric indicators of body composition in young adults: relation to size at birth and serial measurements of body mass index in childhood in the New Delhi birth cohort. Am J Clin Nutr 82:456-466

20. Widdowson EM, Crabb DE, Milner RDG (1972) Cellular development of some human organs before birth. Arch Dis Child 47:652-655

21. Hill DJ (2005) Development of the endocrine pancreas. Rev Endocr Metab Disord 6:229-238

22. Bouwens L, Rooman I (2005) Regulation of pancreatic beta-cell mass. Physiol Rev 85:1255-1270

23. Eriksson J, Forsen T, Osmond C, Barker D (2003). Obesity from cradle to grave. Int J Obes Relat Metab Disord 27:722-727

24. Dahlquist GG, Pundziute-Lycka A, Nystrom L; Swedish Childhood Diabetes Study Group; Diabetes Incidence Study in Sweden (DISS) Group (2005) Birthweight and risk of type 1 diabetes in children and young adults: a population-based register study. Diabetologia 48:1114-1117

25. Dahlquist G (2006) Can we slow the rising incidence of childhood-onset autoimmune diabetes? The overload hypothesis. Diabetologia 49:20-24 